\title{
SERAGAM OLAHRAGA PEREMPUAN DALAM PERSPEKTIF HUKUM ISLAM DAN TEORI SEKSISME
}

\author{
Muhammad Rosyid Ridho \\ UIN Sunan Gunung Djati Bandung \\ muhammadrosyid726@gmail.com \\ Uswatul Khazanah \\ IAIN Ponorogo \\ Uswatulkhasanah28@gmail.com \\ Martha Eri Safira \\ IAIN Ponorogo \\ Marthasafira82@gmail.com
}

\begin{abstract}
:
Women's participation in sports matches has increased every year, not least in the Tokyo 2020 Olympic Games. In the worldof sports, it does not escape some of the controversies that surroundit. Kontroversion is meant here is in terms of the uniforms that athletes wear in competing. One of them was a gymnastics athlete from Germany as well as a Norwegian handball team who were subject to penalties. The case shows that there is discrimination against women through regulations in the use of uniforms.. Looking at this, the authors were interested in researching and analyzing how women's sportswear is viewed from Islamic law and sexism theory, how it impacts and the solution of both theories. The results of this study can be concluded that if it is reviewed from the point of view of hifz al-'ird, the awarding of fines to the athlete is considered unable to meet the protection of honor, especially in the care of dignity and dignity of women As for the actions of female athletes who refuse to wear sports uniforms have been in harmony with the concept of hifz al-'ird. In the view of hifz al-'ird, the uniform worn by athletes must be a uniform that can protect the honor of the athletes while when viewed from the glasses of sexism, it is very clear that there are uniform rules that make women more objects of sexuality in sports.. Supposedly, auniform of a female athlete should be based on the comfort of the athlete who will wear it at sporting events.
\end{abstract}

Keyword: Uniform, hifz al-'ird, sexism

\section{Abstrak:}

Keikutsertaan perempuan dalam pertandingan olahraga mengalami peningkatan setiap tahunnya, tak terkecuali dalam gelaran olimpiade Tokyo 2020. Dalam dunia olahraga, tidak luput dari beberapa kontroversi yang mengitarinya. Kontroversi yang di maksud di sini adalah dalam hal seragam yang dikenakan atlet dalam bertanding. Salah satunya atlet senam dari Jerman serta tim bola tangan Norwegia yang dikenai penalti. Kasus tersebut memperlihatkan bahwa ada diskriminasi terhadap perempuan melalui 
peraturan dalam penggunaan seragam. Melihat hal tersebut, penulis tertarik untuk meneliti dan menganalisis bagaimana pakaian olahraga perempuan ditinjau dari hukum Islam dan teori seksisme, bagaimana dampak dan solusi dari kedua teori tersebut. Hasil dari penelitian ini dapat disimpulkan bahwa jika ditinjau dari sudut pandang hifz al-'ird, pemberian denda pada atlet tersebut dinilai tidak dapat memenuhi perlindungan kehormatan, terlebih dalam penjagaan harkat dan martabat perempuan Adapun tindakan para atlet perempuan yang menolak mengenakan seragam olahraga tersebut telah selaras dengan konsep hifz al-'ird. Dalam pandangan hifz al-'ird, seragam yang dikenakan oleh para atlet haruslah seragam yang bisa melindungi kehormatan para atlet Sedangkan jika dilihat dari kacamata seksisme, terlihat sangat jelas bahwa adanya aturan seragam yang lebih menjadikan perempuan sebagai objek seksualitas dalam olahraga. Seharusnya, aturan seragam atlet perempuan seharusnya berdasarkan kenyamanan atlet yang akan memakainya di event olahraga.

Kata kunci: Seragam, hifz al-'ird, seksisme

\section{PENDAHULUAN}

Keikutsertaan perempuan dalam pertandingan olahraga mengalami peningkatan setiap tahunnya. Hal tersebut dibuktikan dengan meningkatnya partisipasi perempuan dalam gelaran olimpiade Tokyo 2020. Jumlah atlet secara keseluruhan dalam olimpiade Tokyo sebanyak 11.483 dengan rincian atlet laki-laki sebanyak 5.985 dan perempuan 5.498. Persentase partisipasi atlet perempuan sebanyak 48,8\% dari seluruh atlet yang berpartisipasi pada olimpiade Tokyo. ${ }^{1}$ Jumlah tersebut mengalami peningkatan yakni dari Olimpiade Rio sebanyak 45\% dan Olimpiade London 44,2\%.

Dalam dunia olahraga, tidak luput dari beberapa kontroversi yang mengitarinya. Beberapa kontroversi yang di maksud di sini adalah dalam hal pakaian yang dikenakan atlet dalam bertanding. Kontroversi di dunia olahraga yang menjadi perhatian publik diantaranya yaitu datang dari atlet senam dari Jerman yang menggunakan seragam senam yang berbeda di olimpiade Tokyo. Mereka menggunakan seragam dengan body suit berpotongan panjang saat menjalani babak kualifikasi. Hal tersebut tentu mengundang perhatian publik dikarenakan selama ini, atlet senam identik dengan seragam leotart mirip bikini di mana seragam tersebut sudah diperkenalkan oleh pesenam putri sekitar tahun 1970 an. ${ }^{2}$ Seragam bentuk leotart ini mengikuti bentuk tubuh, menutupi lengan dan hanya sampai panggul. Aksi yang dilakukan oleh atlet senam

\footnotetext{
${ }^{1}$ parapuan, "keren ini daftar atlet perempuan yang raih 2 medali di tokyo 2020," parapuan.co, 2021, 1, https:/ / www.google.com/parapuan.co/amp/532830632/keren-ini-daftar-atlet-perempuanyang-raih-2-medali-di-tokyo-2020?page $=2$.

2 fimela.com, "cara atlet perempuan menentang aturan berpakaian seksual dalam olimpiade tokyo 2020," Fimela.com, 2021, 1, https://www.google.com/amp/s/m.fimela.com/amp/4620934/caraatlet-perempuan-menentang-aturan-berpakaian-seksual-dalam-olimpiade-tokyo-2020.
}

IJouGS: Indonesian Journal of Gender Studies | Volume 2 Nomor 2 
Jerman tersebut sekaligus sebagai bentuk menentang seksualisasi dalam senam, sekaligus bertujuan untuk mencegah pelecehan seksual. ${ }^{3}$ Dalam regulasi International Gymnastic Federation (FIG) memang memperbolehkan atlet senam untuk mengenakan leotard one piece dengan panjang penuh sampai pinggul hingga pergelangan kaki, asalkan memiliki design yang elegan. Meskipun hal tersebut diperbolehkan oleh FIG, akan tetapi masih jarang atlet yang menggunakan hal tersebut.

Selain kasus kontroversi dari olimpide Tokyo, ada juga kasus yang menimpa tim bola tangan Norwegia yang dikenai penalti atau denda setelah menolak memakai bawahan bikini saat berlaga dalam kejuaraan eropa yang diadakan oleh federasi bola tangan eropa (EHF) pada tahun 2021. ${ }^{4}$ Mereka dikenai denda sebesar 177 dolar per pemain. Denda tersebut dijatuhkan karena kasus pakaian yang tidak pantas dan menyatakan Norwegia telah bermain menggunakan celana pendek yang tidak sesuai dengan peraturan seragam atlet yang telah ditetapkan oleh federasi bola tangan internasional (IHF). Sebelum itu, induk organisasi internasional bola basket (FIBA) juga melarang penggunaan hijab dalam olahraga basket. Akan tetapi, regulasi FIBA pada akhirnya dirubah pada tahun 2017 dan memperbolehkan atlet perempuan menggunakan jilbab dalam olahraga basket. Kemudian pertengahan tahun 2011 menjelang diandakanya olimpiade london 2011, organisasi bulutangkis dunia (BWF) secara mengejutkan mengeluarkan aturan tentang wacana penggunaan rok mini bagi atlet putri ketika berlaga di turnamen-turnamen level tertinggi BWF. Aturan penggunaan rok mini tersebut dibuat untuk menunjukkan sisi pembeda dalam sebuah permainan bulutangkis putri. Selain itu, BWF juga berdalih bahwa aturan tersebut dibuat sebagai salah satu bentuk promosi tentang bulutangkis agar memiliki popularitas dan penggemar yang luas. Kemudian, BWF juga beranggapan bahwa penggunaan rok mini pada atlet putri bertujuan untuk menarik minat sponsor dan dapat meningkatkan citra bulutangkis di dunia. Hal tersebut juga menuai kecaman dari berbagai negara anggota BWF, sehingga aturan tersebut pada akhirnya dibatalkan.

Melihat dari berbagai kasus di atas, perempuan sering menjadi korban diskriminasi dalam dunia olahraga, hal tersebut karena pelabelan perempuan yang dianggap lebih lemah daripada laki-laki baik secara mental atau pun fisik. Hal tersebut

${ }^{3}$ Bbc, "German Gymnasts' Outfit Take on Sexualisation in Sport," Bbc.com, 2021, 1, https://www.google.com/amp/s/www.bbc.com/news/world-europe-56858863.amp.

4 Bbc, "Tim olahraga yang didenda karena menolak pakai bikini dan seksisme lainnya, bagaimana mengatasinya?," Bbc.com, 2021, 1, https://www.google.com/amp/s/www.bbc.com/indonesia/majalah-57967276.amp. 
tentu menyebabkan diskriminasi terhadap partisipasi perempuan dalam dunia olahraga. Ranah olahraga yang seharusnya menjadi tempat untuk berkompetisi secara fair play dan membahas tentang sportivitas dalam pertandingan, akan tetapi malah menjadi diskriminasi terhadap perempuan melalui peraturan-peraturan dalam penggunaan seragam. seharusnya perempuan diberi kewenangan untuk menentukan pakaian apa yang nyaman dan tidak membahayakkan untuk digunakan dalam berkompetisi di olahraga. sehingga pada akhirnya semua tertuju pada kompetisi olahraga yang sedang dipertandingkan, bukan pada pakaian yang dikenakan.

Melihat hal tersebut, penulis tertarik untuk meneliti dan menganalisis bagaimana pakaian olahraga perempuan ditinjau dari hukum Islam dan teori seksisme, bagaimana dampak dan solusi dari kedua teori tersebut. Di mana perempuan yang berprofesi sebagai atlet dihargai prestasinya dijunjung tinggi harkat dan martabatnya, bukan malah di ekspos dan di eksploitasi dengan dalih untuk kepentingan olahraga.

\section{PEMBAHASAN}

\section{Teori Hukum Islam}

Membahas hukum Islam pastilah lekat dengan tujuan dasar diberlakukan nya hukum Islam tersebut. Tujuan hukum Islam tidak lain adalah untuk kemaslahatan umat manusia. Tujuan yang dimaksud di sini disebut dengan maqashid as-syari'ah. ${ }^{5}$ Maqashid syari'ah merupakan kata majemuk yang terdiri dari dua kata yaitu maqashid dan syari'ah. Secara etimologi maqashid merupakan bentuk jamak dari kata maqshid yang berarti kesengajaan atau tujuan. Sedangkan kata syari'ah secara etimologi berarti membuat syari'at atau undang-undang, menerangkan serta menyatakan. ${ }^{6}$ Secara terminology, maqashid syariah dapat dipahami sebagai konsep untuk mengetahui hikmah (nilai-nilai dan sasaran syara' yang tersurat dan tersirat dalam Alquran dan Hadits) yang ditetapkan oleh Allah terhadap manusia. adapun tujuan akhir hukum tersebut adalah maslahah atau kebaikan dan kesejahteraan umat manusia baik di dunia maupun di akhirat.

Cara untuk mencapai kemaslahatan tersebut adalah dengan terpenuhinya kebutuhan dharuriat (primer), kebutuhan hajiyat (sekunder), dan kebutuhan tahsiniat (tersier). ${ }^{7}$ Kebutuhan dharuriat, dapat didefinisikan secara bahasa yaitu sebagai

${ }^{5}$ Auffah Yumni, “Kemaslahatan dalam Konsep Maqashid al-Syari'ah," Nizhamiyah VI, no. 2 (2016): 47.

${ }^{6}$ Ali Mutakin, "Teori Maqashid Al-Syari'ah dan Hubungannya dengan Metode Istinbath Hukum," Jurnal Kanun 19, no. 3 (2017): 549.

7 Yumni, “Kemaslahatan dalam Konsep Maqashid al-Syari'ah,” 48. 
kebutuhan primer atau dapat juga dikatakan sebagai kebutuhan mendesak. Kebutuhan dharuriat ini sangat diperhatikan, hal ini karena beberapa aspek dalam kebutuhan dharuriat ini sangat menentukan keberlangsungan dalam beragama serta hidup manusia. Tidak terpenuhinya kebutuhan dharuriat ini akan mengakibatkan kehancuran kehidupan manusia secara total. ${ }^{8}$ Adapun kebutuhan hajiyat, jika diartikan dari segi bahasa maka dapat disebutkan sebagai kebutuhan. Kebutuhan hajiyat ini dapat dikatakan sebagai beberapa kebutuhan, yang berguna untuk meringankan kebutuhan dharuriat. Tidak terpenuhinya kebutuhan hajiyat ini hanya akan menimbulkan kesulitan (masyaqqah). Sedangkan kebutuhan tahsiniat jika diartikan secara bahasa memiliki arti sebagai penyempurna. Dalam pandangan umum, kebutuhan ini dianggap baik. Apabila kebutuhan tahsiniat ini tidak terpenuhi, maka kemaslahatan tidak akan hilang atau tidak akan menimbulkan kesulitan (masyaqqah). Kebutuhan tahsiniat bersifat sebagai pelengkap eksistensi kemaslahatan kebutuhan dharuriat serta kebutuhan hajiyat. ${ }^{9}$

Dalam penjelasan sebelumnya, disebutkan bahwa kebutuhan dharuriat merupakan kebutuhan primer atau kebutuhan pokok. Apabila kebutuhan dharuriat tersebut tidak terpenuhi maka terjadi musnahnya kemaslahatan umum. Dengan demikian, kebutuhan dharuriat ini menjadi kebutuhan paling penting dan berada pada urutan pertama dari ketiga kebutuhan yang telah disebutkan di atas. Urutan berikutnya adalah kebutuhan hajiyat, di mana urutan ini lebih rendah daripada kebutuhan dharuriat, dan selanjutnya adalah kebutuhan tahsiniat. ${ }^{10}$ Kebutuhan dharuriat terbagi menjadi beberapa bagian, diantaranya adalah:

1. Perlindungan agama (hifz al-din)

Perlindungan agama menjadi tujuan pertama hukum Islam. Hal ini karena agama merupakan pedoman hidup manusia, yang di dalamnya diatur mengenai cara-cara bersikap sebagai seorang muslim yang berhubungan dengan Tuhannya serta berhubungan dengan sesame manusia dalam kehidupan bermasyarakat. Hukum Islam sendiri bahkan mewajibkan untuk melindungi agama yang dianut oleh seseorang serta menjamin kebebasan dalam beragama sesuai dengan keyakinannya.

${ }^{8}$ Retna Gumanti, “Maqasid Al-Syariah Menurut Jasser Auda (Pendekatan Sistem dalam Hukum Islam)," Jurnal Al-Himayah, no. 2 (2018): 103.

${ }^{9}$ Muhammad Syukri Albani Nasution dan Rahmat Hidayat Nasution, Filsafat Hukum Islam dan Maqashid Syariah (Jakarta: Kencana, 2020), 43-45.

${ }^{10}$ Nasution dan Nasution, 47. 
Beragama menjadi kebutuhan khusus dan utama bagi manusia sehingga beragama menjadi suatu keharusan untuk dipenuhi. ${ }^{11}$

2. Perlindungan jiwa-raga (hifz al-nafs)

Dalam Islam diperintahkan untuk makan serta minum, mengenakan pakaian, serta mempunyai tempat tinggal sebagai upaya untuk memelihara dari kebinasaan. Beberapa perintah tersebut bertujuan sebagai pemeliharaan jiwa. Selain hal tersebut hukum qishash, diyat, serta kifarat merupakan sebagai wujud perlindungan terhadap jiwa yaitu menghindarkan kemudaratan terhadap hal-hal yang dapat mengancam jiwa. ${ }^{12}$

3. Perlindungan harta (hifz al-mal)

Perlindungan harta terlihat dari syariat yang telah mengatur mengenai tata cara pemilikan harta dan larangan mengambil harta milik orang lain secara tidak sah. Eksistensi dari harta di sini dapat terwujud dengan memenuhi syariat tersebut. ${ }^{13} \mathrm{Hifz}$ al-mal secara kontemporer maknanya dapat dikembangkan menjadi pengutamaan dalam sebuah sikap peduli dan peka terhadap sosial, mengembangkan ekonomi, peningkatan kesejahteraan manusia, meminimalisir jarak antara kaya dan miskin, serta mengurangi dan menghilangkan adanya perbedaan antar kelas sosialekonomi. ${ }^{14}$

4. Perlindungan akal (hifz al-'aql)

Keberadaan akal sangat penting dalam pertumbuhan dan perkembangan untuk menggali nilai-nilai agama, dengan demikian keberadaan akal di sini harus dijaga dari hal-hal yang dapat merusaknya. ${ }^{15}$ Menjaga akal dari hal-hal yang dapat merusaknya di sini sebagai wujud perlindungan akal.

5. Perlindungan keturunan (hifz al-nasl). ${ }^{16}$

Perlindungan keturunan dalam hal ini dapat dicontohkan dengan upaya memelihara atau menjaga garis keturunan melalui pernikahan seperti yang telah diatur dalam

11 Yumni, "Kemaslahatan dalam Konsep Maqashid al-Syari'ah," 50.

${ }^{12}$ Diyan Putri Ayu, "Tinjauan Maqashid Syari'ah terhadap Akibat Tindakan Marital Rape dalam UU No. 23 Th. 2014 dan RKUHP," Al-Manhaj 1, no. 2 (2019): 238.

13 Suwarjin, Ushul Fiqh (Yogyakarta: Teras, 2012), 159.

${ }^{14}$ Ainol Yaqin, "Maqashid Al-Syari'ah dalam Pengembangan Metodologi Hukum Islam (Kajian Eksploratif Pemikiran Jasser Auda)," Madania 22, no. 1 (2018): 70.

${ }^{15}$ Abdurrahman Kasdi, "Maqashid Syari'ah dan Hak Asasi Manusia (Implementasi Ham dalam Pemikiran Islam)," Jurnal Penelitian 8, no. 2 (2014): 251.

${ }^{16}$ Jasser Auda, Membumikan Hukum Islam melalui Maqasid Syariah (Bandung: Mizan Pustaka, 2015), 34.

IJouGS: Indonesian Journal of Gender Studies | Volume 2 Nomor 2 
agama dan negara, serta tidak melakukan perbuatan zina. ${ }^{17}$ Pemaknaan hifz al-nasl dapat diperluas menjadi perlindungan serta kepedulian terhadap institusi keluarga. ${ }^{18}$

6. Perlindungan kehormatan (hifz al-'ird)

Sebagian ahli menambahkan hifz al-'ird untuk menggenapkan kelima maqashid itu menjadi enam tujuan pokok atau keniscayaan. ${ }^{19}$ Menurut al-Juwaini, hifz al-'ird disebut sebagai istilah penjagaan kehormatan. Dewasa ini, istilah tersebut dimaknai lebih luas yaitu perlindungan harkat martabat dan hak asasi. ${ }^{20} \mathrm{Hifz}$ al-ird bermakna melindungi diri dari hinaan serta sebagai suatu pedoman yang menjamin harkat dan martabat manusia. ${ }^{21}$ Selain itu, hifz al-'ird juga dimaknai sebagai pelestarian adat dan budaya. Pelestarian adat dan budaya ini merupakan bagian sebagai upaya menjaga kehormatan serta martabat masyarakat. Pemaknaan yang lebih luas lagi, menjaga martabat dan kehormatan bangsa juga merupakan bagian dari hifz al-'ird.22 Selain dimaknai sebagai menjaga harkat dan martabat, hifz al-'ird juga dimaknai sebagai hak asasi manusia. Topik hak-hak asasi manusia dengan Islam telah menjadi pembahasan dalam dunia Islam maupun internasional. Hal ini terlihat dari adanya deklarasi hak asasi manusia dalam Islam Universal pada tahun 1981. Dalam deklarasi tersebut disebutkan ada beberapa hak yang menjadi pembahasan yaitu hak-hak untuk hidup, kebebasan, kesetaraan, keadilan, perlakuan adil, pendapat, kebebasan bersekutu, pendidikan dan kebebasan berkreativitas. ${ }^{23}$

\section{Teori Seksisme}

Seksisme merupakan salah satu bentuk ketimpangan gender yang dialami oleh gender atau jenis kelamin tertentu. Seksisme dapat diartikan sebagai sebuah perlakuan

17 Anis Fitria, Social Entrepreneurship dalam Perspektif Maqashid Al-Syariah, Jurnal Iqtisad, Vol. 4, No. 1 (2018), 17.

${ }^{18}$ Muhammad Iqbal Fasa, Reformasi Pemahaman Teori Maqasid Syariah (Analisis Pendekatan Sistem Jasser Auda), Jurnal Hunafa, Vol. 13, No. 2 (Desember 2016), 232.

${ }^{19}$ Hamka Husein Hasibuan, Pemikiran Maqasid Syariah Jasser Auda, Academia, 12.

${ }^{20}$ Jasser Auda, Membumikan Hukum Islam Melalui Maqasid Syariah, terj. Rosidin dan Ali Abd elMun'im (Bandung: Mizan Media Utama, 2015), 57.

${ }^{21}$ Saibatul Hamdi dan Khabib Musthofa, Menghadirkan Konsep Hifz Al-Irdi dalam Bermedia Sosial: Upaya Menyikapi Asusila Abu-Abu di Youtube, Jurnal El Madani, Vol. 1, No. 02 (2020), 149.

${ }^{22}$ Ahmad Faris dan Washil, Memahami Maqashid Syariah Perspektif Jaser Auda, Jurnal Pemikiran dan Ilmu Keislaman, Vol. 2, No. 1 (Maret 2019), 30.

${ }^{23}$ Sidiq Syahrul, "Maqosid Syari' ah dan Tantangan Modernitas: Sebuah Telaah Pemikiran Jasser Auda," Jurnal In Right 7, no. 1 (2017): 156.

IJouGS: Indonesian Journal of Gender Studies | Volume 2 Nomor 2 
tidak adil terhadap jenis kelamin tertentu, baik laki-laki atau pun perempuan. Akan tetapi, seksisme ini paling sering dialami oleh perempuan, dan berujung sebagai tindakan diskriminasi. Dalam faham seksisme ini, perempuan dianggap sebagai kaum yang lemah dan lebih rendah posisinya daripada laki-laki. Adanya faham seksisme ini, menjadikan perempuan sebagai pihak yang paling rentan dengan diskriminasi dan tidak dihargainya hak-hak dan kemampuan yang dimiliki. Istilah seksisme ini dikenal ketika munculnya gerakan pembebasan perempuan (Woman's Liberation Movement) pada tahun 1960. Pada periode tersebut, para feminis mengatakan bahwa sudah terjadi banyak tekanan terhadap perempuan di berbagai tatanan masyarakat sehingga mulai menyuarakan faham seksisme daripada faham male chauvinisme. ${ }^{24}$ Male chauvinisme merupakan kebaganggan berlebih sebagai sosok maskulin sehingga mengagungkan gender laki-laki. Jauh sebelum itu, pada masyarakat Roma, perempuan tidak memiliki peran yang begitu penting dalam publik, perempuan dilarang untuk menduduki jabatan di publik dan dikecualikan dari semua tugas sipil di publik, sehingga para perempuan tidak dapat menjadi hakim, mengajukan tuntutan, mewakili orang lain di pengadilan dan sebagainya. ${ }^{25}$ Selain itu contoh lain dari seksisme kuno adalah adanya hukum tertulis di mana perempuan dilarang untuk berpartisipasi dalam proses politik. ${ }^{26}$

Seksisme merupakan bagian dari diskriminasi gender, di mana hal tersebut muncul dikarenakan adanya stereotip terhadap peran gender tertentu memiliki posisi yang lebih superior di banding yang lainnya. ${ }^{27}$ Bentuk-bentuk diskriminasi gender tersebut diantaranya yaitu: 28

1. Marginalisasi yaitu proses peminggiran atau pemiskinan perempuan mengakibatkan kemiskinan.

2. Subordinasi yaitu Keyakinan bahwa salah satu jenis kelamin dianggap lebih penting atau lebih penting dibanding lainnya.

3. Stereotype merupakan pembelaan yang memiliki konotasi negatif pada jenis kelamin tertentu.

${ }^{24}$ Rifa Azahra, Maulana Rifai, dan Weni A. Arindrawati, "Representasi Seksisme Dalam Serial Drama Netflix The Queen's gambit Dari Pandangan Roland Barthes," Jurnal Spektrum Komunikasi 9, no. 1 (2021): 25.

${ }^{25}$ Bruce W Frier dan Thomas A.J. McGinn, A Casebook on Roman Family Law (Oxford University Press: American Philological Assosiation, 2004), 457.

${ }^{26}$ Nadia Salama, "Seksisme Dalam Sains," Sawwa 8, no. 2 (2013): 311.

27 Salama, 312.

${ }^{28}$ Rahma Santhi Zinaida, ", "Isu Seksisme dan Feminisme Subaltern Pada Iklan Dalam Bingkai Paradigma Kritis Spivak (Studi Kasus Pada Iklan United Nation Woman pada website www.unwomen.org)," uksw.edu, Tt, 266.

IJouGS: Indonesian Journal of Gender Studies | Volume 2 Nomor 2 
4. Violence (kekerasan) yaitu, serangan fisik atau pun non fisik yang mengakibatkan trauma korbannya.

5. Double burden (beban kerja), yakni bentuk diskriminasi gender dimana beban kegiatan dibebankan pada salah satu gender tertentu.

Seksisme dapat diekspresikan melalui tindakan, perkataan, atau pun kepercayaan dan keyakinan. Seksisme dapat berupa ucapan atau pun perilaku secara sadar atau pun tidak sadar mendiskriminasikan perempuan. Seperti contoh ucapan seksis misalnya adalah melakukan cat calling yaitu seorang yang digoda di jalanan dengan siulan, atau perkataan lain yang menggoda. ${ }^{29}$ Sementara seksisme dalam hal perilaku misalnya yaitu perilaku yang mendiskriminasi dan membatasai perempuan baik dalam kehidupan rumah tangga, di tempat kerja, di dalam organisasi dan kehidupan sosial lainnya. Seksisme dapat pula dilakukan oleh individu, kelompok organisasi, atau pun yang lainnya. Seksisme dapat diwujudkan dengan beberapa kepercayaan atau sikap diantaranya adalah sebagai berikut:

1. Kepercayaan bahwa satu jenis kelamin/ gender yang lebih baik atau lebih berharga dari yang lainnya.

2. Chauvinisme laki-laki atau perempuan

3. Memiliki sifat kebencian terhadap perempuan (misogini) dan kebencian terhadap laki-laki (misandria)

4. Ketidakpercayaan kepada orang yang memiliki jenis gender yang berbeda.

Seksisme itu sendiri terdiri dari tiga manifestasi tingkah laku, yakni tingkah laku overt, covvert dan subtle form. ${ }^{30}$ Seksisme overt merupakan bentuk seksis yang dapat dilihat dan di observasi berbentuk ketidaksetaraan dan perilaku yang dapat merugikan perempuan. Seksisme covert yakni yang termasuk di dalamnya ketidaksetaraan dan perilaku yang dapat merugikan perempuan secara tersembunyi. Sementara itu, seksisme subtle form merupakan bentuk seksis yang melibatkan stereotip yang secara tidak sadar menghasilkan ketidaksetaraan dan merugikan perempuan, yang kemudian menjadi sebuah kebiasaan dikarenakan tidak adanya perhatian khusus atau pun penanganan.

Dalam dunia modern, seksisme ini terdapat dua dimensi yaitu hostle sexism dan benevolent sexism dimana keduanya membentuk sebuah ideologi yaitu sexism ambivalen. Hostle sexism merepresentasikan antipati terhadap perempuan, sementara benevolent

${ }^{29}$ Lutviah, "Seksisme dan Tantangan Kesetaraan Gender," rifka-annisa.org, 2017, 1, https:/ /rifkaannisa.org/id/berita/blog/item/519-seksisme-dan-tantangan-kesetaraan-gender.

30 Putri Miftahul Jannah, "Pelecehan Seksual, Seksisme dan Pendekatan Bystander," Psikobuletin: Buletin Ilmiah Psikologi 2, no. 1 (2021): 64.

IJouGS: Indonesian Journal of Gender Studies | Volume 2 Nomor 2 
sexism yaitu sifat yang menempatkan perempuan dalam posisi yang menyenangkan. ${ }^{31}$ Meskipun faham seksisme ini merupakan hal yang buruk dan melawan hukum, namun masih banyak masyarakat yang melakukan tindakan ini. Paham ini masih tumbuh dan berkembang di masyarakat. Akn tetapi jika terus dibiarkan, maka seksisme ini akan menimbulkan dampak negarif yang justru dapat merugikan, diantaranya yaitu lemahnya performa kognitif, adanya perasaan inkompeten, merasa tidak nyaman, depresi, serta menurunkan self esteem. ${ }^{32}$

\section{Seragam Olahraga Perempuan Perspektif Hukum Islam dan Teori Seksisme}

Ketentuan seragam dalam dunia olahraga menjadi hal yang juga diatur pada sebuah pertandingan. Aturan ini berlaku pada semua atlet, tak terkecuali atlet perempuan. Ketidaktaatan dalam mengenakan seragam ini dapat dikenai denda. Salah satu korbannya yakni atlet bola tangan pantai perempuan Norwegia menjadi bukti adanya denda karena ketidaksesuaian dalam mengenakan seragam dengan aturan. Atlet bola tangan pantai perempuan Norwegia ini didenda karena menggunakan celana pendek, yang seharusnya menggunakan bikini sesuai dengan aturan dalam ajang olahraga bola tangan. Denda yang diterima oleh atlet tersebut sebesar 150 euro atau sekitar 2,5 juta rupiah per pemain atau 1.500 euro atau sekitar 25 juta rupiah untuk satu tim. ${ }^{33}$

Fakta dalam dunia olahraga seperti yang telah dijelaskan di atas jika dibedah dengan teori hukum Islam terlihat sangat jelas adanya kesenjangan. Dalam kajian hukum Islam, ada sebuah kajian terkait tujuan dari syariah. Tujuan dari syariah ini dikenal dengan sebutan maqashid syariah. Maqashid syariah ini berperan penting dalam kajian hukum Islam. ${ }^{34}$ Sesuai dengan tingkatan kemaslahatannya, maqashid syariah dibagi menjadi tiga yaitu, daruriyah, hajiyyah, dan tahsiniyah. Salah satu bagian dari tingkatan daruriyah di sini adalah hifz al-'ird. Hifz al-'ird dimaknai sebagai perlindungan kehormatan. Adapun makna yang lebih luas adalah menjaga harkat dan martabat, serta hak asasi manusia.

31 Jannah, 64.

32 Jannah, 65.

33 fimela.com, "cara atlet perempuan menentang aturan berpakaian seksual dalam olimpiade tokyo $2020, " 1$.

${ }^{34}$ Hamka Husein Hasibuan, "Pemikiran Maqasid Syariah Jasser Auda," Academia.edu, Tt, 12. 
Ditinjau dari sudut pandang hifz al-'ird dalam maqoshid syariah ini, pemberian denda pada atlet tersebut dinilai tidak dapat memenuhi perlindungan kehormatan, terlebih dalam penjagaan harkat dan martabat perempuan. Jika ditelisik lebih dalam, alasan para atlet yang melanggar aturan tersebut karena mereka tidak nyaman dengan seragam yang telah ditentukan oleh federasi olahraga di tersebut. Seragam yang telah diatur oleh federasi olahraga tersebut cenderung mengeksploitasi bagian tubuh para atlet perempuan.

Tindakan para atlet perempuan yang menolak aturan penggunaan seragam yang mengeksploitasi bentuk tubuh perempuan tersebut telah selaras dengan konsep hifz al'ird. Dalam hal ini hifz al-'ird bermakna melindungi kehormatan diri. Kehormatan diri ini harus dilindungi dari segala hal yang dapat merendahkan, merusak serta menjatuhkan nya. Dengan demikian, melindungi kehormatan diri haruslah dilakukan yaitu dengan cara menjaga dirinya dari hal-hal yang bertentangan dengan kehormatan dirinya, seperti tindakan para atlet perempuan tersebut. Salah satu hal yang harus dilindungi demi menjaga kehormatan adalah hal-hal yang berkaitan dengan seksual. Upaya yang bisa dilakukan adalah dengan menjaga cara berpakaian. Cara berpakaian dalam hal ini adalah seragam yang dikenakan para atlet khususnya perempuan. Dengan menjaga pakaian tersebut, atlit perempuan tentu menjaga kehormatan nya dan meminimalisir terjadinya pelecehan seksual di arena pertandingan olahraga.

Melihat pentingnya hifz al-ird (perlindungan kehormatan), maka sudah selayaknya baik diri sendiri maupun orang lain juga turut serta dalam mencapai tujuan dari salah satu maqashid syariah ini. Konsep ini harus diterapkan ke dalam segala aspek kehidupan, tak terkecuali dalam dunia olahraga. Seragam yang dikenakan oleh para atlet haruslah seragam yang bisa melindungi kehormatan para atlet. Seragam yang dimaksud di sini adalah seragam yang tidak menampakkan lekuk tubuh atau pun seragam yang tidak menonjolkan bagian tubuh tertentu para atlet serta yang dapat menimbulkan hasrat seksual bagi yang melihatnya.

Adapun jika dilihat dari kacamata seksisme, terlihat sangat jelas bahwa adanya aturan seragam yang lebih menjadikan perempuan sebagai objek seksualitas dalam olahraga. Bagaimana tidak, jika dilihat dari paparan di atas, adanya pengaturan seragam bagi atlet perempuan tidak menunjukkan sisi kenyamanan atlet, akan tetapi lebih mengarah pada eksploitasi bentuk tubuh atlet perempuan. Dalam sebuah survei yang dilakukan di Inggris, Amerika Serikat, Perancis, Jerman, Italia, Spanyol, Australia dan Selaindia baru menunjukkan bahwa 51 persen laki-laki sebagai penggemar olahraga perempuan, mereka menganggap bahwa olah raga perempuan lebih menginspirasi, 
berorientasi keluarga dan lebih bersih. Dalam survei tersebut yang lebih mencengangkan bahwa sebanyak 31 persen pria menganggap bahwa olahraga perempuan dapat merangsang atau meningkatkan gairah seksual. ${ }^{35}$ Hal tersebut tidak lain dikarenakan penggunaan seragam atlet perempuan yang lebih menunjukkan lekuk tubuh mereka. Aturan seragam yang menonjolkan sisi lekuk tubuh perempuan tentu menarik perhatian para penonton yang melihatnya, tak terkecuali oleh lawan jenis.

Adanya regulasi tentang aturan seragam atlet perempuan dalam olahraga ini terkadang bertujuan untuk menonjolkan penampilan feminim mereka, juga ada pula yang bertujuan agar perempuan tidak terlalu memamerkan kesan terbuka terhadap tubuh mereka. Selain itu, adanya aturan seragam tersebut bertujuan untuk menarik promosi dari para penonton dan sebagai salah satu cara untuk menarik minat sponsor. Perempuan dianggap sebagai sebuah ikon yang menarik dalam sebuah olahraga, di mana perempuan mampu mendatangkan keuntungan bagi olahraga tersebut. Steorotype yang berkembang tentang perempuan merupakan objek yang menarik perhatian dalam ranah olahraga ini juga kurang baik, hal tersebut dikarenakan menariknya sisi feminise perempuan ini, merupakan bagian dari bentuk seksisme di dunia olahraga. Adanya objektifikasi terhadap tubuh atlet perempuan menjadikan sebuah kebingungan siapa yang berhak memutuskan pakaian seragam atlet, federasi yang menaungi atlet atau atlet sebagai orang yang menjalankan pertandingan di lapangan. Adanya tujuan sebagaimana di sebutkan di atas, tentu sama sekali tidak ada hubungannya dengan dunia olahrga. Hal-hal seperti di atas jika terus dibiarkan akan menjadi sebuah budaya, di mana perempuan terus dijadikan sebagai sasaran diskriminasi di dunia olahraga dengan berdalih aturan penggunaan seragam yang membuat para atlet kurang nyaman.

Aturan seragam atlet perempuan seharusnya tidak ditentukan oleh uang dan kepentingan komersil akan tetapi berdasarkan kenyamanan atlet yang akan memakainya di event olahraga. Budaya mengekang atau mempersulit para atlet perempuan melalui penggunaan seragam merupakan seuatu hal yang tidak dibenarkan dan cenderung mendiskriminasi perempuan. Alih-alih dilihat dari prestasi dan kemampuan nya dalam olahraga, para atlet perempuan masih di lihat serta di nilai dari pakaian yang mereka gunakan. Solusi terbaik dari adanya seksisme dalam aturan seragam pemain perempuan ini adalah bagaimana para pembuat regulasi mengubah cara pandang, sikap dan perilaku agar hal tersebut tidak merugikan perempuan sebagai korban dalam aturan

35 aem.hr, "Recommendation for better coverage of woman's sport in electronic media," aem.hr, 2020, 30, https://www.aem.hr/wo/content/uploads/2020/02/preporuke-zene-i-sports-EN.

IJouGS: Indonesian Journal of Gender Studies | Volume 2 Nomor 2 
seragam ini. Perlawan terhadap seksisme ini merupakan salah satu cara agar agar di kemudian hari tidak ada lagi kasus-kasus diskriminasi yang dialami oleh atlet perempuan.

\section{PENUTUP}

Menurut perspektif hukum Islam, dalam hal ini adalah maqashid syariah, dan dikhususkan pada hifz al-ird pemberian denda pada atlet yang melanggar ketentuan seragam yang telah ditentukaan oleh federasi dinilai tidak dapat memenuhi perlindungan kehormatan, terlebih dalam penjagaan harkat dan martabat perempuan. Adapun tindakan para atlet perempuan yang menolak mengenakan seragam olahraga tersebut telah selaras dengan konsep hifz al-'ird. Dalam pandangan hifz al-'ird, seragam yang dikenakan oleh para atlet haruslah seragam yang bisa melindungi kehormatan para atlet. Sedangkan, jika dilihat dari kacamata seksisme, terlihat sangat jelas bahwa adanya aturan seragam yang lebih menjadikan perempuan sebagai objek seksualitas dalam olahraga. Adanya pengaturan seragam bagi atlet perempuan tidak menunjukkan sisi kenyamanan atlet, akan tetapi lebih mengarah pada eksploitasi bentuk tubuh atlet perempuan. Seharusnya, perempuan yang berprofesi sebagai atlet diberikan keleluasaan memilih seragam yang ingin ia kenakan, dalam artian seragam tersebut nyaman dan tidak membahayakan atlit itu sendiri. Sehingga seksisme dalam aturan seragam atlet perempuan ini kedepanya bukan menjadi budaya yang menjadikan diskriminasi perempuan di dunia olahraga.

\section{DAFTAR RUJUKAN}

aem.hr. "Recommendation for better coverage of woman's sport in electronic media." aem.hr, 2020. https://www.aem.hr/wo/content/uploads/2020/02/preporuke-zene-isports-EN.

Ayu, Diyan Putri. “Tinjauan Maqashid Syari'ah terhadap Akibat Tindakan Marital Rape dalam UU No. 23 Th. 2014 dan RKUHP." Al-Manhaj 1, no. 2 (2019).

Azahra, Rifa, Maulana Rifai, dan Weni A. Arindrawati. "Representasi Seksisme Dalam Serial Drama Netflix The Queen's gambit Dari Pandangan Roland Barthes." Jurnal Spektrum Komunikasi 9, no. 1 (2021). 
Bbc. "German Gymnasts' Outfit Take on Sexualisation in Sport." Bbc.com, 2021. https://www.google.com/amp/s/www.bbc.com/news/world-europe56858863.amp.

- - - “Tim olahraga yang didenda karena menolak pakai bikini dan seksisme lainnya, bagaimana mengatasinya?" Bbc.com, 2021. https://www.google.com/amp/s/www.bbc.com/indonesia/majalah57967276.amp.

fimela.com. "cara atlet perempuan menentang aturan berpakaian seksual dalam olimpiade tokyo 2020." 2021. https://www.google.com/amp/s/m.fimela.com/amp/4620934/cara-atletperempuan-menentang-aturan-berpakaian-seksual-dalam-olimpiade-tokyo2020.

Frier, Bruce W, dan Thomas A.J. McGinn. A Casebook on Roman Family Law. Oxford University Press: American Philological Assosiation, 2004.

Gumanti, Retna. "Maqasid Al-Syariah Menurut Jasser Auda (Pendekatan Sistem dalam Hukum Islam)." Jurnal Al-Himayah, no. 2 (2018): 1.

Hasibuan, Hamka Husein. "Pemikiran Maqasid Syariah Jasser Auda." Academia.edu, Tt. Jannah, Putri Miftahul. "Pelecehan Seksual, Seksisme dan Pendekatan Bystander." Psikobuletin: Buletin Ilmiah Psikologi 2, no. 1 (2021).

Kasdi, Abdurrahman. "Maqashid Syari'ah dan Hak Asasi Manusia (Implementasi Ham dalam Pemikiran Islam)." Jurnal Penelitian 8, no. 2 (2014).

Lutviah. "Seksisme dan Tantangan Kesetaraan Gender." rifka-annisa.org, 2017. https://rifka-annisa.org/id/berita/blog/item/519-seksisme-dan-tantangankesetaraan-gender.

Mutakin, Ali. “Teori Maqashid Al-Syari'ah dan Hubungannya dengan Metode Istinbath Hukum." Jurnal Kanun 19, no. 3 (2017).

Nasution, Muhammad Syukri Albani, dan Rahmat Hidayat Nasution. Filsafat Hukum Islam dan Maqashid Syariah. Jakarta: Kencana, 2020.

parapuan. "keren ini daftar atlet perempuan yang raih 2 medali di tokyo 2020." parapuan.co, 2021. https://www.google.com/parapuan.co/amp/532830632/keren-ini-daftaratlet-perempuan-yang-raih-2-medali-di-tokyo-2020?page $=2$. 
Salama, Nadia. "Seksisme Dalam Sains." Sawwa 8, no. 2 (2013).

Suwarjin. Ushul Figh. Yogyakarta: Teras, 2012.

Syahrul, Sidiq. "Maqosid Syari'ah dan Tantangan Modernitas: Sebuah Telaah Pemikiran Jasser Auda." Jurnal In Right 7, no. 1 (2017).

Yaqin, Ainol. "Maqashid Al-Syari'ah dalam Pengembangan Metodologi Hukum Islam (Kajian Eksploratif Pemikiran Jasser Auda)." Madania 22, no. 1 (2018).

Yumni, Auffah. "Kemaslahatan dalam Konsep Maqashid al-Syari'ah." Nizhamiyah VI, no. 2 (2016).

Zinaida, Rahma Santhi. ", "Isu Seksisme dan Feminisme Subaltern Pada Iklan Dalam Bingkai Paradigma Kritis Spivak (Studi Kasus Pada Iklan United Nation Woman pada website www.unwomen.org),." uksw.edu, Tt. 